Government Policies for Corporate Social Responsibility in Europe:

A Comparative Analysis of Institutionalisation

Knudsen, Jette Steen; Moon, Jeremy; Slager, Rieneke

Published in:

Policy and Politics

Publication date:

2015

Document version

Early version, also known as pre-print

Citation for published version (APA):

Knudsen, J. S., Moon, J., \& Slager, R. (2015). Government Policies for Corporate Social Responsibility in Europe: A Comparative Analysis of Institutionalisation. Policy and Politics, 43(1), 81-99. 


\title{
article
}

\section{Government policies for corporate social responsibility in Europe: a comparative analysis of institutionalisation}

\author{
Jette Steen Knudsen, Department of Political Science, \\ Copenhagen University, jsk@ifs.ku.dk \\ Jeremy Moon, Nottingham University Business School, \\ Jeremy.moon@nottingham.ac.uk \\ Rieneke Slager, Nottingham University Business School, \\ rieneke.slager@nottingham.ac.uk
}

This paper analyses policies of 22 European Union member governments, designed to encourage corporate social responsibility (CSR) between 2000 and 2011. It categorises these policies by their regulatory strength and identifies the range of issues to which CSR policies are directed. The paper argues that Northern European, Scandinavian and UK governments are reconstructing their respective institutional structures to embed CSR concerns more explicitly therein. It concludes that these government CSR initiatives are converging, particularly around their increased regulatory strength and the broadening of their issue application. Policies in Mediterranean and the former communist countries do not reflect increasing institutionalisation.

Keywords: corporate social responsibility (CSR) • government policies • Europe

\section{Introduction}

Our paper focuses on how national governments encourage corporate social responsibility (CSR) and the issues that these policies address. This is counterintuitive for two reasons. First, much new governance literature tends to downplay the role of national government, reflecting literatures on policy communities and network governance, and latterly on global governance. Combining these, literatures have emerged around private voluntary global governance to fill the regulatory welfare voids.

Second, much CSR literature downplays the role of government and some excludes it axiomatically on the grounds that if social investments were a response to regulation they could not be deemed voluntary (for example, McGuire, 1963; McWilliams and Siegel, 2001); a view endorsed by the European Commission's initial definition of CSR as 'a concept whereby companies integrate social and environmental concerns in their business operations and in their interaction with stakeholders on a voluntary basis' (EC, 2001, emphasis added). 
Other CSR literatures, however, take the more expansive view that CSR refers to the way in which business manages its impacts upon society (Gond et al,2011) and the most recent EU definition reflects this shift: 'the responsibility of enterprises for their impacts on society' (EC, 2011). Thus the strict assumption of voluntarism as the sine qua non of CSR has diminished, reflecting the view that CSR is 'embedded' (Moon and Vogel, 2008) in national (and international) institutions, including legitimised business practices and relationships, and public policies (Campbell, 2007; more broadly, see Fligstein, 1996; Granovetter, 1985). Hence government policies for CSR, the focus of our paper, have been integrated into the CSR field. McBarnet (2007), for example, notes the variety of soft regulation to encourage CSR. Alberada et al (2006, 2007, 2008), Steurer (2009) and Steurer et al (2008) have identified European CSR public policies. Other scholars have investigated the relationships between types of policymaking systems and types of CSR (Midttun et al, 2006; Matten and Moon, 2008; Gjølberg, 2009), often using 'national business systems' (for example, Whitley, 2002) and 'varieties of capitalism' (VoC) (for example, Hall and Soskice, 2001) frameworks.

Our paper develops the insights of these literatures. Drawing from a large data set covering 22 countries it addresses three questions:

1. What types of policies, in terms of their regulatory strength, do governments use to encourage CSR?

2. What issue areas have these policies addressed?

3. What is the cross-national variation in government CSR policy trends?

On this basis, the paper advances the study of CSR and government in five ways:

1. systematically updating EU member governments' CSR policies;

2. making key comparative CSR policy insights by:

- identifying limitations of the VoC literature,

- including Mediterranean and former communist countries, and

- identifying CSR policies for international as well as domestic issues;

3. identifying the different regulatory strengths of CSR policies using the Fox et al (2002) classification of CSR public policies (endorse, facilitate, partner, mandate);

4. identifying the changing issue focus of CSR policies by adopting a new indicator in this literature: the ministries responsible for the policies;

5. yielding a framework for the analysis of policies for CSR combining the regulatory strength of the policies with their issue application.

These contributions are introduced in the following sections.

\section{Europe-wide analysis of government policies for CSR}

Our analysis of policies from 22 countries enables a more representative account of CSR policies in Europe than hitherto. Moon et al's (2012) literature review found about 40 papers on government and CSR in Europe. Only a few of these claimed EU-wide coverage and even these reflected selectivity (for example, Albareda et al, 2007; Riess and Welzel, 2006; Welzel et al, 2007). Only three other papers contained 
six or more countries, two of which focused on western Europe (Rivera-Lirio and Muñoz-Torres, 2010; Steurer, 2009) and the other on Central and Eastern Europe (Braendle and Noll, 2006). Two focused on two or three countries (Italy, UK:Albareda et al, 2006; Italy, UK, Norway: Albareda et al, 2008). The remaining papers identified addressed only one country: the UK (12 papers); Spain (three); Germany and France (two each); and Austria, Italy, Slovakia and Sweden (one each). The attention to the UK may be explained by its reputation as an early mover (Moon, 2005) and a leader in policies for CSR (Welzel et al, 2007).

On the grounds of empirical coverage alone, our paper is innovative.

\section{Comparative analysis of CSR policies}

Albareda et al (2007) offer the widest coverage of European CSR policies $(n=15)$ to date, inductively distinguishing several country groupings. The 'partnership' model (Scandinavia, the Netherlands), reflected national policy traditions and focused policies on the environment. The 'business in the community' model (Ireland, the UK) reflects 'soft regulation' for local social and economic problems. The 'sustainability and citizenship' model (central Europe) reflects 'solidaristic' traditions of 'social market economies' to address broad sustainability challenges. The 'agora' model (Mediterranean countries) reflects the challenge of creating consensus through dialogue.

Other comparative CSR studies are more theoretically grounded in the literatures of 'national business systems' (Whitley, 2002), 'diversity of capitalism' (Amable, 2003), and VoC (Hall and Soskice, 2001; Deeg and Jackson, 2007; Kristensen and Morgan, 2012; Martin and Thelen, 2007) which distinguish liberal (LME) and coordinated market economies (CME). Reflecting Crouch's (2005) distinction between two institutional complementarities, CSR is understood to fit in with domestic institutional structures by either 'substituting' (Jackson and Apostolakou, 2010; Kinderman, 2012; Matten and Moon, 2008) or 'mirroring' (Campbell, 2007; Gjølberg, 2009) extant government policies.

We suggest, that these interpretations may be overly didactic to account for CSR policies and note with Aguilera et al (2007) and Midttun et al (2006) that although governments and companies operate in environments which are structured, actors, including governments, retain some choice. We anticipate some limitations in the usefulness of the VoC model to account for comparative European CSR policies for three reasons.

First, the evidence of comparative CSR problematises VoC-based interpretations. For example, the classification of the UK as a LME belies the historic power of labour, public sector size, and state role in health and welfare in the UK (Crouch et al, 2009), which may make for different policy approaches to CSR than those of the USA as suggested by the UK's CSR reputation (see above). One might also expect rather different approaches to CSR among CME countries, given that Scandinavian governments are distinguished by their national and international social democratic ideals (Campbell, 2007), whereas Northern European (or Rhenish) governments administer systems of capitalism characterised by national consensus among labour and capital (Albert, 1991). Second, the VoC approach offers limited theoretical foundation for analysis of Mediterranean (Albareda et al, 2007; Cantó-Milà and Lozano, 2009) and 'post-communist' governments (Braendle and Noll, 2006). Yet these are as vital to an understanding of European CSR policies as any other group of governments. 
Third,VoC literature is grounded in domestic policy environments, yet preliminary research suggests that CSR may partly reflect international issues (Matten and Moon, 2008) and that governments may be motivated to introduce internationally oriented CSR policies (Brown and Knudsen, 2013).

We now turn to the analytical contributions of our paper, first concerning the regulatory strength of policies (1.3) and the second concerning their issue focus (1.4).

\section{The regulatory strength of CSR policies}

The paper adopts the framework of Fox et al (2002) to distinguish four types of policy to encourage CSR: 'endorsement, facilitation, partnering, and mandate'. This framework has been used for studies of developing countries (Fox et al, 2002), of single countries (for example, Moon, 2005), and for conceptual purposes (Gond et al, 2011). It has not, however, been used in empirical analysis of European government CSR policies.

Other comparative analyses of European government policies for CSR tend both to be inductive and offer classifications which are nominal and combine regulatory style, issue focus and intended styles of business-society relations. Hence Albareda et al (2007) distinguish: 'partnership; business in the community; sustainability and citizenship'; and Agora policies; and Steurer (2009) distinguishes: 'legal, economic, informational, partnering and hybrid policy instruments'.

In contrast our framework enables insights from the perspectives of comparative public policy and of government and CSR into how government policies for CSR vary by their 'regulatory strength'. This is because the four policy types are distinguished by the government resources upon which they draw. We can therefore provide insights into the general concerns of regulatory theory, shared by the comparative public policy and CSR fields, concerning the costs and benefits of a variety of means of changing behaviour.

Although regulatory theory includes economics (for example, Stigler, 1970), law (for example, Braithewaite 2008), and political science approaches (for example, Moran 1986), there is shared interest in the relative strength of different regulatory types. The interest in the regulatory effects of cultural norms (Hancher and Moran, 1989) is captured in our schema by 'endorsement' which draws upon and renews shared values about business and society through political support. The interest in incentives is captured by 'facilitation' which involves structuring markets through subsidy schemes and tax incentives. The interest in semi-formal or network relations among actors (Rhodes, 1990) is captured by 'partnerships' involving collaboration of government organisations with firms or business associations, in which public sector bodies can function as participant or convenor. Most obviously, the interest in authority (Williamson, 1975; Levi-Faur, 2011) is captured in our schema by 'mandate', which involves the definition of minimum standards for responsible business performance embedded within a legal framework. There is a related interest in the different uses of mandate, particularly to shape 'responsive regulation' (Braithewaite, 1992), which Moon and Vogel (2008) suggest may be pertinent to government policies for CSR.

Thus our framework offers insights into the underlying regulatory strategies of government policies for CSR. Specifically, we can distinguish the policies which embed CSR in wider national institutions from those which encourage it at arm's- 
length from governmental institutions for social, economic, political and environmental regulation based on the following assumptions:

- 'mandate' reflects the strongest regulation for CSR, requiring regulation and even legislation, and would usually involve other governmental resources associated with the other three forms of policy;

- 'facilitation' and 'partnership' policies reflect medium levels of regulatory strength, requiring governments to substantiate their commitment to encouraging CSR by, for example, providing financial and organisational resources;

- 'endorsement' represents relatively weak regulation for CSR, for while it signals government approval of CSR, there are no further resources to redirect company behaviour, and CSR would remain at arm's-length from government.

The four policy types are defined and their respective regulatory strengths are distinguished in Table 1.

Table 1: CSR policies and their regulatory strength

\begin{tabular}{|c|c|c|}
\hline $\begin{array}{l}\text { Type of } \\
\text { policy }\end{array}$ & Description & $\begin{array}{l}\text { Regulatory strength entaile } \\
\text { in policies }\end{array}$ \\
\hline Endorse & $\begin{array}{l}\text { Political support for CSR through general } \\
\text { information campaigns and websites, political } \\
\text { rhetoric, award and labelling schemes }\end{array}$ & Low regulatory strength \\
\hline Facilitate & $\begin{array}{l}\text { Incentives for companies to adopt CSR through } \\
\text { subsidies or tax incentives; public procurement }\end{array}$ & Medium regulatory strength \\
\hline Partner & $\begin{array}{l}\text { Collaboration of government organisations with } \\
\text { business organisations to disseminate knowledge } \\
\text { or develop/maintain standards, guidelines and so } \\
\text { on }\end{array}$ & Medium regulatory strength \\
\hline Mandate & $\begin{array}{l}\text { Regulation of minimum standards for business } \\
\text { performance }\end{array}$ & High regulatory strength \\
\hline
\end{tabular}

Linking our analytical approach with our comparative ambition, we expect government policies for CSR to differ according to the broad interpretations of comparative political economy. First, we expect endorsing CSR policies wherever governments sought to encourage CSR as these would underpin other forms of intervention. Due to its relative weakness, however, we would expect it to be especially prevalent in LMEs which, according to VoC literature, refrain from strong market regulation. We expect the former communist governments to develop CSR policies, which are consistent with the LME model ideationally adopted in 1989. We expect Mediterranean governments to adopt endorsing CSR policies, due to their relatively weak government institutions.

Second, we expect facilitating policies throughout but especially in Northern Europe and Scandinavia where governments are long distinguished for their preparedness to intervene in markets. While we would expect some forms of partnering CSR policies throughout, we these to be especially prevalent in Scandinavia because of the traditions of consensus and deliberation in these countries' public policies.

Finally, we would expect mandating policies to be most common in Northern Europe and Scandinavia, given their propensity for rules-based approaches to economic and 
social management (Campbell, 2007; Andersen et al, 2012). We would not expect them in the LMEs, the Mediterranean and the former communist systems.

\section{The issue focus of CSR policies}

This brings us to our fourth contribution: the innovative use of government ministries as an indicator of the issue areas to which CSR policies are respectively addressed. This indicator has been used to analyse long-run governmental activities (Moon and Sayers, 1999). Moon and Sayers (1999) note that ministries are good indicators of the general scope of government priorities because they capture government activities irrespective of whether they are law, finance or personnel intensive and are thus immune from the weaknesses of singular legal, financial and employment measures of policy (Rose, 1984). The constitutional and political significance of ministries (for example, concerning authority and responsibility) is core to the functioning parliamentary democracy, which defines all the countries in our study.

This indicator allows us to identify domestic issue areas (for example, social, environmental, economic) and international purposes (for example, trade, development) for which governments deploy CSR. This contrasts with Steurer's approach of assigning a classification of CSR issues, which he calls four 'thematic fields of action': to 'raise awareness, improve transparency, foster socially responsible investment and lead by example' (2009), which risks excluding issue areas to which governments might seek to direct CSR policies. Our approach enables identification of how the respective CSR policies are understood by governments to fit into their overall systems of policy organisation, that is, the ministries.

\section{A CSR policy framework: regulatory strength and issue focus}

The extant literature on CSR policies is descriptively rich, albeit in a relatively narrow range of countries. As there is little conceptualisation of CSR policies our fifth contribution offers a two dimensional framework based on regulatory strength and issue focus to improve analysis of government and CSR across political systems and time. These two dimensions reflect fundamental points of CSR evaluation, its relationship to law and governance, and its overall societal contribution. Together they provide an indicator of the levels of CSR institutionalisation. The framework is presented in the final section: Conclusions and discussion.

In the next section we describe our research methodology, and in the third section we present our findings and analysis, followed by the concluding and discussion section.

\section{Methodology}

We collected data on government policies for CSR from 2000 to 2011. The data for the 22 countries were aggregated into five groups, broadly informed by the comparative literatures:

- three Scandinavian countries (Denmark, Finland, Sweden);

- two Anglo-American countries (Ireland and the UK); 
- $\quad$ seven former communist countries (Bulgaria, Czech Republic, Hungary, Poland, Romania, Slovakia, Slovenia);

- six Northern European countries (Austria, Belgium, France, Germany, Luxembourg, the Netherlands); and

- four Mediterranean countries (Greece, Italy, Portugal, Spain).

We defined a policy as a governmental output or public action: 'the substance of what government does' (Dearlove, 1973,2). This would be identified by the mobilisation of public resources such as regulations, financial resources (negative or positive expenditures), organisational resources, or cultural/political resources.

CSR policies are those designed to encourage responsible business behaviour but not to require it. This distinguishes CSR policies from straight requirements to behave in certain ways, which governments may impose on individuals or organisations. However, this raises the question of how much regulation is needed for a policy to be a simple rule rather than a CSR policy, which would entail some level of corporate discretion as to whether or how to respond. Our test for distinguishing CSR policies from simple command and control regulation is to answer the following questions:

1. Does the policy establish requirements for compliance?

2. Does the policy establish penalties for non-compliance?

If both questions are answered 'yes' we would not speak of CSR policies, but of command and control regulation.

Data regarding CSR policies and responsible ministries were collected from an extensive web-search and several published sources (see Appendix 1). Expert researchers classified the policies according to our endorse/facilitate/partner/mandate framework and according to the responsible national government ministries. It should be noted that in many countries multiple departments may have had some relationship to CSR and these are recorded accordingly.

\section{Findings and analysis}

We present and analyse our findings in two sections. First, we present our findings on the types of policies directed to CSR. Second, we identify the issue areas to which the CSR policies are addressed. Each section also summarises how the findings reflect our comparative expectations among the five regional groupings.

\section{Types of policies for CSR}

\section{CSR endorsement policies}

Endorsement policy instruments raise awareness of CSR and promote good practices. They involve providing political support for, and affirmation of, CSR and related initiatives (Fox et al, 2002). We found many examples of endorsement policies including general information campaigns and websites, political rhetoric, award and labelling schemes.

Endorsement policies aimed at awareness-raising are common across Europe.Various German ministries host websites related to CSR and sustainable development, and 
UK government departments engage in knowledge dissemination activities. Political rhetoric is another form of endorsing CSR, including what Albareda et al (2007) refer to as the 'agora model' in Spain, Greece, Italy and Portugal designed to involve a broad range of stakeholders to develop a social consensus around CSR policies.

Policies to create national award schemes that reward companies for good social and/or environmental CSR programmes exist in the UK, Ireland, Denmark (see Riess and Welzel, 2006; Brown and Knudsen, 2013), Germany, Austria, Greece, Portugal, Spain, Bulgaria, Hungary, Slovakia and Slovenia. Some are long-standing, such as the Austrian Federal Ministry for Social Security competition rewards for the enterprise with the best equal opportunity and family friendly policy, which has run since 1999. Newer schemes include the Bulgarian award for the socially responsible enterprise of the year, started in 2006 .

We found that all European governments adopted endorsement policies in the form of political support and affirmation, educational activities, awareness campaigns and guidelines; however, they amounted to a greater proportion of all policy instruments in the Mediterranean countries, consistent with Albareda et al's (2007) appellation of the 'agora' model. Our analysis also reveals that these countries were less likely than the others to use facilitation, partnering and mandate. This may reflect the relatively weak institutional frameworks extant on which basis facilitation, partnering and mandate might have been premised.

\section{CSR facilitation policies}

The facilitating role requires a more active role for governments than entailed in policies which endorse CSR, as it involves enabling or incentivising companies to develop CSR (Fox et al, 2002,3). CSR facilitation policies are found throughout Europe, though only modestly in Mediterranean countries. These policies mainly include subsidies and tax expenditures for contributions to charities, the adoption of clean technologies, and the employment of disadvantaged workers in public procurement policies. Significantly from a VoC perspective, LME governments also featured here.

Even within the facilitation policy type, there is varying regulatory strength. At one extreme, tax incentives for charitable giving promote corporate philanthropy, without regulating the targets for donation. In contrast, sustainable procurement policies direct CSR more closely by specifying standards for suppliers to adhere to. In 2003 the UK government introduced sustainable procurement specifications. In 2005 a Sustainable Procurement Task Force was created to measure progress against targets set for all government departments.

We found some examples of tax incentives related to social and environmental activities throughout Europe. In countries as diverse as Sweden, Italy, Bulgaria, Poland and the UK, payroll giving schemes encourage employees to donate to charities by authorising a deduction from their gross pay before tax (Welzel et al, 2007).

In former Communist countries such as Bulgaria, Hungary and Romania, incentive schemes stimulate diversity and equal opportunities by granting tax relief for companies employing previously long-term unemployed workers. Tax relief schemes to stimulate ethical or green investment exist in the Netherlands and Belgium. Germany, the Netherlands, Belgium, Spain, and Portugal have subsidy schemes to support CSR, including environmental and social subsidy schemes. 


\section{CSR partnership policies}

The partnering CSR policy role involves collaboration with firms or business associations, in which governmental roles vary from participant to convenor. Like policies to facilitate CSR, partnering requires a greater level of governmental commitment than endorsement. Partnership approaches assist in disseminating knowledge about CSR and sustainability issues, while sectoral partnerships often play a key role in the development of guidelines, standards or codes. We find evidence of partnering policies throughout Europe. For example, the Austrian, German, Italian and Swedish governments introduced CSR multi-stakeholder forums (Riess and Welzel, 2006).

More intensive partnering agreements exist in the UK and Denmark where the governments founded and provide core funding for the Ethical Trading Initiative, alliances of companies, trade unions and NGOs committed to improving working conditions in global supply chains.

Thus, partnering policies for CSR usually entailed collaboration with firms or business associations, and the creation of multi-stakeholder initiatives, particularly to ensure supply chain standards arising from the internationalisation of business. There was evidence of partnering in most European countries, the Mediterranean apart.

\section{CSR mandate policies}

Policies that mandate behaviour involve the specification of some minimum standard for business performance embedded within the regulatory framework (Fox et al, 2002). Mandating involves governments taking the most definitive role in CSR through regulations and decrees, even though these, by definition, fall short of being classified as 'command and control' policies.

Numerous governments implemented non-financial reporting legislation. The law on the New Economic Regulation of 2001 and a further decree in 2002 detail the reporting provisions for listed companies in France to encourage companies to establish the tools to measure their social and environmental impacts. Regulation also exists in France regarding senior management reporting on financial risks. The Danish non-financial reporting requirement relates to large firms only (Brown and Knudsen, 2013). Hungary's Recommendations on Social Responsibility of 2010 made by the Economic and Social Council also include a suggestion to make sustainability reporting obligatory for companies in which the Hungarian government has a majority stake, and similar recommendations were made by the Polish Working Group on CSR in 2011. Several governments including France, Belgium and the UK, have also legislated public pension fund reporting requirements.

We note that the mandating form of CSR policy has become increasingly significant, particularly for non-financial reporting and other transparency requirements both for companies and for pension funds. Consistent with theVoC literature, a mandating role remains a key policy instrument in France (and also in Scandinavia and to some extent in other Northern European countries). In addition, the mandating instrument is not as the VoC literature would predict widely deployed in Mediterranean countries. We also confirmed our expectation that the former communist countries have been reluctant to move towards mandated CSR policies, apart from when complying with 
EU environmental policies. In contrast to our expectations based on theVoC literature and Albareda et al (2007), however, the UK has adopted mandate policies for CSR.

In summary, a number of countries utilised a full range of endorsement, facilitation, partnership and mandate policies, most notably the UK, Northern Europe and Scandinavia. We see these as embedding CSR most 'deeply' by virtue of this use of the full regulatory range. Although endorsement policies are widespread, they tend to dominate the range of policies in the Mediterranean countries. Partnership and mandate policies are widespread but are relatively popular in Scandinavia, Northern Europe and the UK.

\section{Issue focus of CSR policies}

We distinguished the sorts of issues which government CSR policies address by identifying the ministerial departments and portfolios attributed responsibility for the policies (Table 2).

In most of the countries, CSR was originally assigned to Social and Employment ministries. However, there has been a subsequent widening of the range of domestic problems to which governments deploy CSR, first to Environment and then to Economic ministries, such that by 2011 about two thirds of national governments had Social and Employment, Environmental and Economic ministries (including Trade and Industry) with some CSR responsibility. In addition to the international element of CSR captured in the 'Trade and Development' type of Economic ministries, one third of the countries $(n=8)$ have now assigned CSR to Foreign Affairs or International Development ministries. This indicates that national CSR policies extend well beyond domestic concerns.

Today, in most countries, the responsibility for CSR policies is placed in several ministries and in some of these (for example, Belgium, France, Poland, the UK) the governments also designate one of these to lead and coordinate cross-departmental efforts.

This broadening of issue areas towards which CSR policies are directed is a powerful indicator of the widening range of governance challenges for which governments see CSR as offering a suitable approach.

The countries which attached CSR to a full set of Social/Employment, Environmental, Economics, and Foreign and Development ministries are one of the three Scandinavian countries (Denmark), two of the seven North European countries (France, Germany), one of the four Mediterranean countries (Italy), and one of the two Anglo-Saxon countries (the UK - which attached CSR to the widest range of ministries). Thus the breadth of the application of CSR to policy issues increases as one moves from the former Communist and the Mediterranean countries, to Northern Europe, Scandinavia and the UK. Thus we conclude that the latter three government types are likely to embed CSR most 'broadly' by dint of the breadth of the issue areas to which CSR policies are applied.

\section{Conclusions and discussion}

Our first conclusion is to confirm that governments in Europe make policies for CSR. Moreover, they appear to do so both by employing an increasingly wide range 


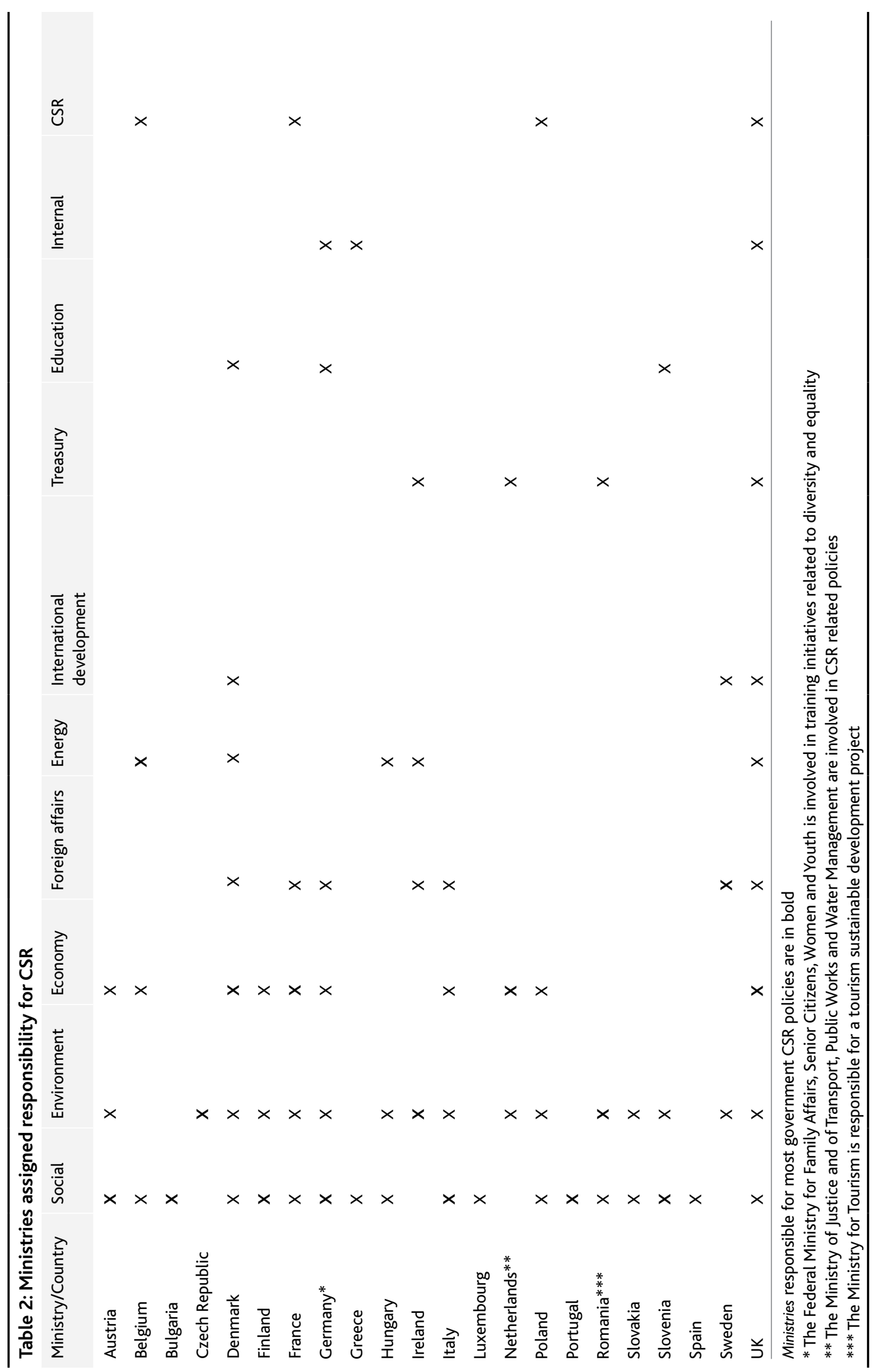


of regulatory instruments (from endorse, through facilitation and partnership, to mandate), and by applying CSR to an increasing broad set of issue areas.

Looking first at the regulatory instruments employed, we identify a trend of governments in all European countries to at least endorse CSR, and in most cases to bringing stronger policy initiatives to bear. However, the trend appears to have been structured by certain comparative capitalism considerations. Most obviously governments in the Mediterranean and the former communist systems principally devise endorsement policies for CSR, which can be interpreted as bringing relatively low regulatory strength to bear.

The comparative stress placed on partnerships in Scandinavia also confirms our expectations, as do those policies for CSR in Scandinavia through facilitation and mandate. Countries in Northern Europe also shared a greater use of facilitation and mandate, as we had expected on the basis of the comparative capitalism literature. However, contrary to the expectations generated by this literature, the UK also used the stronger regulatory instruments of facilitation, partnership and mandate.

This raises a question for further research as to why the UK stands out so markedly. Is this exceptionalism a function of the UK government being an early mover in developing CSR policies which are complementary or 'similar' (Crouch, 2005) to public policies (Moon, 2004) or is it more about the CSR policies reflecting CSR as part of a neo-liberal complementarity in 'contrast' (Crouch, 2005) to wider public policies or a substitution for a previous policy regime (Kinderman, 2012)?

Our data are not able to confirm this either way. On the one hand it might be concluded that because the UK and Scandinavian governments have introduced ethical trade partnerships and non-financial reporting requirements, the explanation for these policies must be similar notwithstanding their different institutional settings. Conversely, it is perfectly possible that while the names of the policies appear similar, they are quite different in terms of complementarity with existing policies. Gjølberg (2009) takes this view about the comparable high CSR status in Nordic and UK companies, arguing that the UK's CSR reflects a need to support the international competitiveness of the many large and globally oriented British multinationals (see also Thompson and Kaspersen, 2012), but that in Scandinavia it reflects the general commitment to social-democratic norms and an ability to translate conformance with government social and environmental regulation in CSR. Case study research could be used to investigate how, for example, two nominally similar CSR policies (for example, ethical trade standards, reporting requirements) are enacted in two such different business systems.

Another related area of further research concerns the role of governments in Northern Europe in pursuing policies, which encourage business initiatives outside their more traditional neo-corporatist style of policy-making. Given that they are using facilitation (medium regulatory strength) and especially mandate (high regulatory strength) to encourage CSR, it appears that they are thereby re-institutionalising their own policy frameworks - and in many cases, doing so across a wide range of policy areas (see below). The paradox here is that governments in the very systems which Matten and Moon (2008) identified as having 'implicit' CSR embedded in wider systems of responsibility, are encouraging their companies to make their CSR more 'explicit' in order to be seen to be complying with governmental regulations. Certainly, this appears broadly consistent with the findings of Thatcher's (2007) comparative analysis of reform in French and German (and UK) regulatory 
institutions. However, further case study research could investigate whether this reinstitutionalisation amounts to departures from or mirroring of conventional policy frameworks in these systems.

Our second main findings concern the increasing breadth of issue areas to which governments address CSR. We have seen a general trend of expansion from domestic social, through domestic environmental, through domestic economic, to international issues. However, this trend also appears to be structured by comparative considerations. The Scandinavian and UK governments which are most likely to apply CSR to the full range of issues and the Mediterranean and former communist country government adopt more selective and tentative approaches. This appears to reflect Scandinavian confidence in the capacity of 'governed' CSR to usefully complement existing policy parameters. The UK case again sticks out as a puzzle and the types of interpretation fleshed out above could equally apply here. Case study research could also be usefully directed here to clarify governmental motivations.

Combining our two sets of findings on the varying strength of CSR regulation employed and the varying breadth of issues to which CSR is applied by governments, enables us to address the question of whether there a relationship between the types of policy instruments chosen (endorsing, facilitating, partnering, mandating) and the types of issues to which the policies are addressed. We can distinguish some overarching trends when we aggregate CSR policies across all countries. Social/ employment issues such as CSR training and skills provision are most often addressed through endorsing (for example, information provision, labels), while human and labour rights are often addressed through partnering type policies (for example, multi-stakeholder forums). Limited facilitating policies also exist for social issues through tax incentives for corporate philanthropy. Environmental issues, such as energy efficiency and climate change, are addressed in an even wider range of policy types, ranging from endorsing (for example, information provision, labels) through to facilitating (for example, 'green' investment schemes) and mandating (for example, climate change regulations). Several types of policies address social and environmental issues through endorsing (for example, awards) or facilitating (for example, public procurement). Corporate governance issues, such as CSR reporting or bribery, are in the main addressed through mandating type policies, although we found less evidence of this type of policy overall. Lastly, policies addressing issues with a more economic focus such as socially responsible investing (SRI) and fair trade are addressed through partnering type policies (fair trade) and mandating (SRI). In summary, we see social issues being addressed through policy types that require limited government involvement, corporate governance/economic issues being addressed through policy types requiring strong government involvement, while types of government involvement in environmental issues ranges broadly.

Finally, by combining the two sets of findings, our analysis enables some broad insights into how CSR is institutionalised by governments into their general public policy frameworks. Table 3 presents a typology of government CSR policies according to their 'strength' and 'breadth'. The first dimension, strength, distinguishes weak, medium and strong policies. In general terms we would see the endorsing policies as relatively weak: they are supportive of CSR as a set of business practices. The inference here is that CSR is something that the government wants to support but it does so in such a way as not to impact upon its own policy settings: it is more 'arm's-length' and about business-society relations. In contrast, the facilitating and partnering policies 


\begin{tabular}{|c|c|c|c|}
\hline & \multicolumn{3}{|c|}{ Breadth of policy application } \\
\hline \multirow{4}{*}{$\begin{array}{l}\text { Strength of } \\
\text { government } \\
\text { policy }\end{array}$} & & Partial & Broad \\
\hline & Low & $\begin{array}{l}\text { Selective } \\
\text { support }\end{array}$ & Systemic support \\
\hline & Medium & Selective steering & Systemic steering \\
\hline & High & Selective institutionalisation & Systemic institutionalisation \\
\hline
\end{tabular}

bring more government resources and usually entail a specific intended direction of business behaviour: they appear to steer CSR. Mandating policies are ostensibly the strongest, and often also entail explicit elements of the other three policy types, and as a result are the most likely to institutionalise CSR. The inference here is that governments build CSR into their own policy settings by applying not only incentive structures and organisational investments (that is, facilitation and partnerships), but also through regulation. As a result CSR policies in these cases are not simply about encouraging new forms of business-society relations, but are also about governmentbusiness-society relations.

The second dimension, the breadth of CSR policies, distinguishes partial and broad application of CSR policies. In general terms the more partial application reflects governmental selection of a few policy areas (for example, social, environmental).The inference here is that CSR is an appropriate adjunct to public policy and that public policy can advance CSR but only in reference to certain issue areas. The broader applications reflect a more systemic spread of CSR policies (for example, social, environmental, economic, international). The inference here is that CSR policies are relevant to government policies broadly, and that government policies can advance CSR, across a wide range of issue areas.

Integrating our dimensions of strength and breadth of government policies for CSR, we are able to distinguish broad types of government CSR strategy:'selective support'; 'systemic support';'selective steering';'systemic steering';'selective institutionalisation'; and 'systemic institutionalisation' (Table 3). These are ideal types in the Weberian sense but are generated and underpinned by our empirical findings.

In the Northern European, Scandinavian and UK systems there is clear development from 'selective support' towards 'systemic institutionalisation'. What explains this shift in general terms? More specifically, are the governments in these countries reconfiguring their own institutional frameworks by incorporating CSR therein, as suggested by Gond et al (2011)? This question is particularly pertinent in the cases of Northern European and Scandinavian governments whose institutional systems had been identified as inhibiting the development of 'explicit' CSR by Matten and Moon (2008).

Numerous avenues for further research follow from our paper, which case study research can help address. These include how and why some governments see CSR as having systemic relevance while other governments make policies which suggest that they see CSR as of partial relevance. In the case of those who see system-wide applications of CSR, what coordination mechanisms do they introduce and how effective are these? Conversely, is CSR simply a solution in search of policy problems (Lindblom, 1959) and if so, how and why? 
Finally, some limitations need to be noted with our study. While our method allows comparative 'face value' discrimination among types of government policies for CSR, it can hardly be said to capture the full texture of business-government relations in the respective countries. Moreover, there may be a problem of commensurability in the assumptions about what is collectively referred to as 'CSR policy' in the 22 countries in question.

Second, there are limitations in our approach, reflecting the realities of comparative government effectiveness. For example, in some national systems soft mandatory policies are effective in securing widespread compliance, whereas in others they are met with non-compliance (Rivera-Lirio and Muñoz-Torres, 2010). In some cases, policies may be adopted for 'symbolic' reasons (Edelman, 1964) and in others for more substantive policy purposes. In short, our analysis does not confirm the extent to which any particular policy was effective in making business more responsible.

However, with these limitations in mind we have provided a comprehensive comparative account of European government policies for CSR in terms of their respective strength and breadth, on the basis of which we have offered a government policy for CSR framework, and identified key avenues for further research.

\section{References}

Aguilera, RV, Williams, CA, Conley, JM, Rupp, D, 2007, Corporate governance and social responsibility: A comparative analysis of the UK and the US, Corporate Governance: An International Review 14, 3, 147-58

Albareda, L, Tencati,A, Lozano, J, Perrini, F, 2006, The government's role in promoting corporate responsibility: A comparative analysis of Italy and UK from the relational state perspective, Corporate Governance 6, 4, 386-400

Albareda, L, Lozano, J,Ysa, T, 2007, Public policies on corporate social responsibility: The role of governments in Europe, Journal of Business Ethics 74, 4, 391-407

Albareda, L, Lozano, J, Tencati, A, Midttun, A, Perrini, F, 2008, The changing role of governments in corporate social responsibility:Drivers and responses, Business Ethics: A European Review 17, 4, 347-63

Albert, M, 1993, Capitalism against capitalism, London: Whurr

Amable, B, 2003, The diversity of modern capitalism, Oxford: Oxford University Press

Andersen, SK, Lubanski, N, Pedersen, O, 2012, After flexicurity: Mobility and education as the new axis in European employment policies? Paper for session: After flexicurity: European scenarios for balanced employment policies, at ILERA World Congress, Philadelphia

Baldwin, R, Cage, M, 1999, Understanding regulation:Theory, strategy and practice, Oxford: Oxford University Press

Braendle, UC, Noll, J, 2006, Enlarged EU: Enlarged corporate governance? Why directives might be more appropriate for transition economies, Corporate Governance 6, 3, 296-304

Braithewaite, J, 2008, Regulatory capitalism: How it works, ideas for making it work better, Cheltenham: Edward Elgar

Brown, D, Knudsen, JS, 2013, The role of domestic institutions and market pressures as drivers of corporate social responsibility (CSR): An examination of company CSR initiatives in Denmark and the UK, Political Studies, http://ssrn.com/ abstract $=2154856$ and http://dx.doi.org/10.2139/ssrn.2154856 
Campbell, J, 2007, Why would corporations behave in socially responsible ways? An institutional theory of corporate social responsibility, Academy of Management Review 32: 946-67

Cantó-Milà, N, Lozano, J, 2009, The Spanish discourse on corporate social responsibility, Journal of Business Ethics 87: 157-71

Crouch C, 2005, Complementarity and fit in the study of comparative capitalisms, in G Morgan, R Whitely, E Moen (eds) Changing capitalisms: Internationalisation, institutional change, and systems of economic performance, New York, NY: Oxford University Press, pp 167-89

Crouch, C, Schröder, M, Voelzkow, H, 2009, Regional and sectoral varieties of capitalism, Economy and Society 38, 4, 654-78

Dearlove, J, 1973, The politics of policy in local government, Cambridge: Cambridge University Press

Deeg, R, Jackson, G, 2007, Towards a more dynamic theory of capitalist variety, Socio Economic Review 5, 1, 149-80

EC (European Commission), 2001, Green paper: Promoting a European framework for corporate social responsibility, COM (2001) 366 final, presented by the Commission of the European Union, Brussels, 18 July

EC (European Commission), 2010, GPP national action plans, http://ec.europa.eu/ environment/gpp/action_plan_en.htm

EC (European Commission), 2011, A renewed EU strategy 2011-14 for corporate social responsibility, COM (2011) 681 final, Brussels, 25 October

Edelman, MJ, 1964, The symbolic uses of politics, Urbana:The University of Illinois Press Fligstein, N, 1996, The economic sociology of the transitions from socialism, American Journal of Sociology 101, 4, 1074-81

Fox, T, Ward, H, Howard, B, 2002, Public sector roles in strengthening corporate social responsibility, Washington DC: World Bank

Friedman, M, 1970, The social responsibility of business is to increase its profits, New York Times, 13 September

Gjølberg, M, 2009, The origin of corporate social responsibility: Global forces or national legacies?, Socio-Economic Review, 7, 605-37

Gond, J-P, Kang, N, Moon, J, 2011, The government of self-regulation: On the comparative dynamics of corporate social responsibility, Economy and Society 14, 4, 640-71

Granovetter, M, 1985, Economic action and social structure: The problem of embeddedness, American Journal of Sociology 91, 3, 481-501

Hall, PA, Soskice, D, 2001, Varieties of capitalism: The institutional foundations of comparative advantage, Oxford: Oxford University Press

Jackson, G and Apostolakou, A, 2010, Corporate social responsibility in Western Europe:An institutional mirror or substitute?, Journal of Business Ethics 94, 371-94

Kinderman, D, 2012, Free us up so we can be responsible! The co-evolution of corporate social responsibility and neo-liberalism in the UK, 1977-2010, SocioEconomic Review 10, 1, 29-57

Knopf, J, Kahlenborn, W, Hajduk, T et al, 2010, Corporate social responsibility: National public policies in the European Union, Directorate-General for Employment, Social Affairs and Equal Opportunities, Berlin: Adelphi 
Kristensen, PH, Morgan, G (eds), 2012, Theoretical contexts and conceptual frames for the study of $21^{\text {st }}$ century capitalisms, Oxford: Oxfordkn University Press, introductory chapter

Lindblom, CE, 1959, The science of 'Muddling through', Public Administration Review 19, 2, 79-88

McBarnet, D, 2007, CSR beyond law, through law, for law: The new corporate accountability, in D McBarnet, A Voiculescu, T Campbell (eds) The New corporate accountability: CSR and the law, Cambridge: Cambridge University Press, pp 9-56

McGuire, JW, 1963, Business and society, New York: McGraw-Hill

McWilliams, A, Siegel, D, 2001, Corporate social responsibility: a theory of the firm perspective, Academy of Management Review 26, 117-27

Martin, CJ,Thelen, K, 2007, The state and coordinated capitalism: Contributions of the public sector to social solidarity in post-industrial societies, World Politics, 60, 1,1-36

Matten, D, Moon, J, 2008, 'Implicit' and 'explicit' CSR:A conceptual framework for a comparative understanding of corporate social responsibility, Academy of Management Review 33, 2, 404-24

Midttun, A, Gautesen, K, Gjølberg, M, 2006, The political economy of CSR in Western Europe, Corporate Governance:The International Journal of Business in Society 6, 4, 369-85

Moon, J, 2005, CSR in the UK. An explicit model of business: Society relations, in A Habisch, J Jonker, M Wegner, R Schmidpeter (eds) CSR across Europe, Germany: Springer-Verlag, pp 51-65

Moon, J, Sayers, A, 1999, The dynamics of governmental activity: A long-run analysis of the changing scope and profile of Australian ministerial portfolios, Australian Journal of Political Science 34, 149-67

Moon, J,Vogel, D, 2008, Corporate social responsibility, government and civil society, in A Crane,A McWilliams, D Matten,J Moon, DS Siegel (eds) The Oxford handbook of corporate social responsibility, Oxford: Oxford University Press

Moon, J, Slager, R, Brunn, C, Hardi, P, Knudsen JS, 2012, Analysis of the national and EU policies supporting corporate social responsibility and impact, IMPACT working paper 2, 'IMPACT Project', European Commission (Framework 7 Program), http:// csr-impact.eu/documents/documents-detail.html?documentid=5

Moran, M,1986, Theories of regulation and changes in regulation:The case of financial markets, Political Studies 34, 2, 185-201

Riess, B, Welzel, C, 2006, Government as partner? CSR policy in Europe, Bertelsmann Stiftung,www.bertelsmann-stiftung.de/cps/rde/xbcr/SID-58917186-B87CCE34/ bst/Government_as_partner_Study_mit_Bild.pdf

Rivera-Lirio, J, Muñoz-Torres, M, 2010, The effectiveness of the public support policies for the European industry: Financing as a contribution to sustainable development, Journal of Business Ethics 94, 4, 489-515

Rose, R, 1984, Understanding big government: The programme approach, London: SAGE

Scherer, AG, Palazzo, G, 2011, The New political role of business in a globalized world: A review of a new perspective on CSR and its implications for the firm, governance, and democracy, Journal of Management Studies 48, 4, 899-931

Steurer, R, 2009, The role of governments in corporate social responsibility: Characterising public policies on CSR in Europe, Policy Sciences 43, 1, 49-72 
Steurer, R, Margula, S, Berger, G, 2008, Public policies on CSR in EU Member States: Overview of government initiatives and selected cases on awareness raising for CSR, sustainable public procurement and socially responsible investment, ESDN Quarterly Report June 2008, www.sd-network.eu/?k=quarterly\%20reports\&report_id=9

Stigler, GJ, 1971, The theory of the regulatory state, The Bell Journal of Economics and Management Science 2, 1, 3-21

Strand, RC, 2012, In praise of corporate social responsibility bureaucracy, $\mathrm{PhD}$ Dissertation, Copenhagen Business School http://openarchive.cbs.dk/ handle/10398/8462

Tencati,A, Perrini, F, Pogutz, S, 2004, New tools to foster corporate socially responsible behaviour, Journal of Business Ethics 53, 1-2, 173-90

Thatcher, M, 2007, Reforming national regulatory institutions: The EU and crossnational variety in European network industries, in B Hancke, M Rhodes and M Thatcher (eds), Beyond varieties of Capitalism: Conflict, contradictions and complementarities in the European Economy, Oxford: Oxford University Press,147-172

Thompson, G, Kaspersen, LB, 2012, The globalization of the business sector in a small open economy: the case of Denmark and its wider implications, Socio-Economic Review 2012, 1-27

Welzel, C, Peters, A, Höcker, U, Scholz, V (eds), 2007, The CSR navigator public policies in Africa, the Americas, Asia and Europe, Bertelsmann Stiftung and GTZ, www.bertelsmann-stiftung.de/cps/rde/xbcr/bst/CSR_Navigator_lang.pdf

Whitley, R (ed), 2002, Competing capitalisms: Institutions and economies, Cheltenham: Edward Elgar

\section{Appendix 1}

\section{Methods}

1. Three overview sources were used to form the preliminary data base: Knopf et al: Corporate Social Responsibility - National public policies in the European Union (2010); CSR Europe: A guide to CSR in Europe; Country Insights by CSR Europe's National Partner Organisations (2009); UNDP Accelerating CSR practices in the new EU member states and candidate countries as a vehicle for harmonisation, competitiveness and social cohesion in the EU (2007).

The following combinations of terms were googled:

$$
\begin{aligned}
& \text { - } \quad \text { Corporate; responsib*; policy; the name of the country } \\
& \text { - } \quad \text { CSR policies; CSR programs; the country } \\
& \text { - Sustainab*; policy; the country } \\
& \text { - } \quad \text { Promot }^{\star} \text {; responsib*; the country } \\
& \text { - } \quad \text { Promot }{ }^{\star} \text {; sustainab*; the country } \\
& \text { - Government; CSR; the country. }
\end{aligned}
$$

Resultant google references led to various public policies government websites. Each website found was then searched for further policies. 
2. A search was conducted of current government websites for Corporate Social Responsibility, CSR; Corporate Responsibility; CR; Sustainab^; Responsib^.

3. A number of country specific inquiries were made to solicit any reference to polices that the above searches may have missed. These included national legal sources (for example, the Hungarian Legal Catalogue), local UNDP offices (for example, in the case of CEE countries), and national CSR experts.

4. Data were gathered by a team of researchers, which enabled any language barriers to be overcome in most cases.

5. A final qualitative check was made to ensure that policies found met our basic parameters (for example, in the UK, CSR also stands for Comprehensive Spending Review!). 